\title{
Development Opportunity Of Floating Net Cage (Fnc) System- Trevally (Caranx Spp.) Culture Business In Amurang District, South Minahasa Regency, North Sulawesi, Indonesia
}

\author{
Eva Maryani Rita Mukuan ${ }^{1 *}$, Sukoso $^{2 *)}$ Diana Arfiati ${ }^{3)}$, Rene Ch. Kepel ${ }^{4)}$

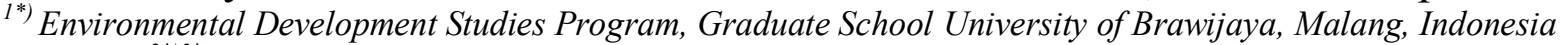 \\ $\left.2^{*}\right)^{*}$ Faculty of Fisheries and Marine Science, University of Brawijaya, Malang, Indonesia \\ ${ }^{4 *)}$ Faculty of Marine Science and Fishery, University of Sam Ratulangi, Manado, Indonesia
}

\begin{abstract}
Business opportunity and prospect of floating net cage system-trevally culture were studied in Amurang District based on its financial aspects. Trevally culture is one of alternative livelihoods of coastal communities in Amurang district in order to reduce the dependence upon fishing activities towards overexploitation. Data collection used purposive sampling, intentionally selecting Ranoyapo and Bitung villages, trevally culture business centre in Amurang district, as study site. For this, 30 respondents of fish farmers were selected for their business feasibility analysis.

This study was aimed at knowing the feasibility level and the profit of the trevally culture business in Amurang district. The feasibility analysis used Net B/C Ratio, Internal Rate of Return (IRR), Rate of Return On Investment (ROI), Payback Period (PBP), and Break Even Point (BEP) calculations. Results showed that B/C ratio of 1.17 , production BEP of $18.409 \mathrm{~kg}$ and production price BEP of Rp. 35,066/kg. Rate of Return on Investment (ROI) obtained was 10.56 months. The profitability (ROI) was $1.58 \%$ and IRR was $85.27 \%$. As conclusion, trevally culture in Amurang district, South Minahasa regency is feasible to develop as an alternative livelihood, but it needs to have strategic steps to be able to raise production and gain, such as seedling and food supply, so that trevally culture could become one of the alternative businesses to develop in the coastal area of Amurang district.
\end{abstract}

Keywords: Trevally culture business, business feasibility, financial analysis.

\section{Introduction}

South Minahasa Regency has a coastal area with $168.22 \mathrm{~km}$ of coastaline facing Sulawesi Sea with an area of 56.00 ha (4 miles). Fisheries communities in the area comprise 11,548 fishermen, 811 fish sellers, 1,540 fish farmers and 438 fish processor (Anonimous, 2011)

The sustainable potency of Indonesia marine fisheries resources is 6.4 million tons per year, including demersal fish 1.36 million tons and coral fish 145 thousand tons. Exploitation is allowed as much as $80 \%$ of the sustainable potency or about 5.12 million tons per year (Nikujuluw 2002).

Mariculture is highly potential to develop in the coastal waters of Amurang district since it is supported by extensive marine coastal waters and good water conditions for maricultural business. Nevertheless, the areal use for mariculture is very low, $22 \mathrm{Ha}$ for seaweed culture, $218 \mathrm{Ha}$ for floating net cage culture, and $0.1 \mathrm{Ha}$ sea cucumber culture, respectively.

One of mariculture businesses that could be developed in the coastal waters of South Minahasa Regency is trevally culture in the floating net cage (FNC). Trevally ( Caranx spp.) is one of highly potential fish species to develop due to their comparative superiority as follows (Anonimus, 2001), i.e. capable of living in high density (150 ind./m2), high growth rate, highly reactive to food addition, sufficiently efficient food conversion, and consumer's high preference.

Beside encouraging export development, FCN system-fish culture development also becomes an alternative solution in solving natural population reduction as a result of intensive fishing activities and coral reef destruction as trevally habitat (Sudirman, 2008).

Trevally culture with floating net cage system has not been developing in the coastal waters of South Minahasa Regency if compared to the present potency. Field conditions indicate that this fish culture is just developed in Amurang, $10 \mathrm{Ha}$, and West Amurang, $5 \mathrm{Ha}$, districts, respectively. Amurang district is one of the areas starting the development of the floating net cage system-trevally culture business. Low interest of the community to do this culture business could result from capital limitation, difficulty to get seedlings and insufficient knowledge and technological mastery.

Since the mariculture potency is relatively large, the limitation of mariculture potency utilization, low preference to do the trevally culture in FNC system despite high economic value, and many problems 
encountered in the trevally culture business in the FNC, information on trevally culture business opportunity in the FNC is needed.

This study was aimed at knowing the magnitude of gains and business feasibility obtained from floating net cage system-trevally culture in Amurang district, South Minahasa Regency. Business analysis is absolutely done, if someone wants to start the business in order to measure or calculate whether the trevally culture is profitable or not. Business analysis gives the farmer some illustrations to plan the business. (Supriadi, 2009)

\section{Research Method}

This study used survey method using interviews and direct observations in the trevally culture location. The former used questioneers covering respondent identity, biotechnical, economic, and institutional variability in FNC-trevally culture business, environmental impacts, and problems encountered. The respondents targetted in this survey was those who ran the FNC system-trevally culture in the costal waters of Amurang district, particularly Ranoyapo and Amurang villages. General approach used to achieve the study objective was through primary and secondary data collection. The former came from various previous studies through observational data collection. Data analysis was descriptively carried out and development feasibility analysis through Net B/C Ratio, Internal Rate of Return (IRR), Rate of Return On Investment (ROI), Payback Period (PBP), and Break Even Point (BEP) calculations.

According to Giatman (2006), to know the business feasibility, the business activity analytical method was used with several criteria as follows:

a. Business profit

Gross profit of one-period culture activity is the difference between total revenue and total operational cost (variable cost and fixed cost). Net profit is the profit after tax as much as $15 \%$.

Profit $=$ Total revenue - Total Operational Cost

b. Profit Rate/Capital Efficiency

Profit obtained in a business can reach certain percent of total cost spent, the ratio between net business profit and total operational cost (fixed cost + variable cost) multiplied by $100 \%$

c. Business Feasibility (B/C Ratio)

Benefit Cost Ratio is the ratio between net gains and total operational cost (fixed cost and variable cost). If $\mathrm{B} / \mathrm{C}$ ratio is bigger than 1 , the business is not feasible to run.

d. Net Present Value (NPV)

Net Present Value is number of present cash flow minus the investment capital considered as investment cost in certtain time period in which the NPV is highly affected the discount rate established. The NPV was calculated using Giatman (2006)

$\mathrm{NPV}=\sum_{\mathrm{ot}}^{\mathrm{n}} \mathrm{CF}_{\mathrm{t}}$ (PIF)

where

$\mathrm{CFt}=$ Cash Flow Total (benefit + cost $)$

PIF $=$ Present Interest Factor.

e. Break Even Point

This analysis is intended to know how many products must be sold or how much the selling price is that a company does not get loss.

Break Even Point (BEP) consists of 2 analyses, (1) break even point as a result of total cost and product unit price ratio of business break even point calculation achieved in number of certain fish production and (2) production price break even point as a result of total cost and total production ratio, the business break even point achieved at certai product price per $\mathrm{kg}$ fish.

Production $\mathrm{BEP}=$ total operational cost/unit product price

Production price $\mathrm{BEP}=$ total operational cost/total production

f. Capital Return

The capital spent as business cost capital will return in several harvest periods is the ratio between total operational cost (fixed cost and variable cost) and net profit.

Capital return $=$ total operational cost $/$ net profit

e. Capital Efficiency

Profit gained in a business can reach certai percent of total cost spent is the ration between net profit and total cost (fixed cost and variable cost) multiplied by $100 \%$.

Capital efficiency $=($ net profit $/$ total cost $) 100$

f. Internal Rate of Return (IRR)

IRR is the interest rate within a specified period that makes the NPV of the project equal to zero.This analysis aims to determine the level of internal gains derived from investment. 
g. Profitability (ROI)

Investment return period is calculated based on profit.

Profitability $=($ net profit/total investment $) 100$

\section{Results and Discussion}

Business analysis is very important activity done before beginning a business in order to have a figure on business feasibility and benefit obtained. The trevally business analysis highly varies, and it results from that the operational cost estimation used is dependent upon the extent of the business unit, equipment and material used and site position.

\section{Investment Technical Analysis}

The cost needed for floating net cage system-trevally culture in South Minahasa regency consists of investment cost and working capital.

The former covers $8 \mathrm{~m} \times 3 \mathrm{~m}$-raft construction with $3-2.5 \mathrm{mx} 3 \mathrm{mx} 2.5 \mathrm{~m}$ bags and the availability of canoe and working tools.

The latter includes seedling supply cost, food cost and worker's wages, and maintenance cost.

Financing those cost components is calculated based on prices in Amurang district or South Minahasa regency undr several following assumptions:

1) Economic period of 3 years

2) Funds come from Bank loan with an interest rate of $12 \%$ per year for 3 year period.

3) Income tax as much as $15 \%$

4) Rearing period of 5 months or 2 cycles a year

5) Selling price of Rp. $40,000 / \mathrm{Kg}$

6) Seedlings stocked are $10 \mathrm{~cm} \times 3 \mathrm{~cm}$ size as many as 1000 individuals a rearing cycle with mortality rate of $15 \%$ and body weight of $350 \mathrm{gr} / \mathrm{ind}$.

7) Rearing period is 5 months.

Based on those assumptions, the investment cost and the operational cost are presented in Table 01.

$\underline{\text { Table 01. Investment and Production Cost Estimation (for } 10 \mathrm{FNC} \text { ) }}$

\begin{tabular}{lcc}
\hline \multicolumn{1}{c}{ Component } & Total (Rp) & $\%$ \\
\hline Investment Cost & 65.550 .000 & 31,33 \\
Fixed Cost & 49.381 .000 & 23,61 \\
Variable Cost & 94.277 .500 & 45,06 \\
& & \\
\hline Total Cost & 209.208 .500 & 100 \\
\hline
\end{tabular}

Total cost needed for 10 units of the floating net cage system-trevally culture in Amurang district is Rp. 209,208,500 in which the largest is the variable cost reaching $45.06 \%$. The contribution to the extent of the variable cost is fish food. The trevallies Amurang district were fed averagely $5 \mathrm{~kg}$ trash fish/day obtained from fishing around the waters of Amurang district.

Compared with FNC system-grouper culture in Tatapaan district, South Minahasa regency, in which the total cost needed for 10 units was 3,029,897,979 (Eva.M,2011), trevally culture business requires relatively lower cost. Detail investment cost, variable cost and fixed cost needed for the FNC system-trevally culture in Amurang district is given in appendix 1.

\section{Profitability Analysis}

1) Business Profit

The objective of any business is to obtain profits, and it could be gained if total gain is higher than total expenditures. The business profit of FNC system-trevally culture in Amurang district is given in Table 02.

Table 02. Benefit-Cost Analysis of Trevally Culture of Floating Net Cage in Amurang District.

\begin{tabular}{rlr}
\hline No. & \multicolumn{1}{c}{ COMPONENT } & TOTAL (Rp.) \\
\hline 1 & Total Cost & 620.040 .810 \\
2 & Total Gain & 840.000 .000 \\
3 & Total Gain before tax & 219.959 .190 \\
4 & Income tax (15\%) & 22.943 .879 \\
5 & Total Gain after tax & 186.969 .312 \\
\hline
\end{tabular}

Table 02 shows that the net gain for a 3-year-trevally culture business of $10 \mathrm{FNC}$ units in 6 production cycles reduced by the income tax is Rp. 186,969,312 or Rp. $63,323,104$ per year or Rp. 31,161,552 per cycle. It means that the trevally culture could give the farmer profit since the net gain obtained is higher than the expenditure. 
2) Profit Rate

Provit Rate is a calculation to know the capital efficiency through consideration of the business profit volume relative to the total operational cost. The profit rate of the trevally business in Amurang district is as follows:

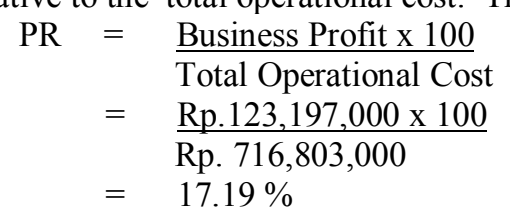

It means that in 3 years the trevally culture business gives the profit as much as $17.19 \%$ which is above the bank loan interest, $12 \%$.

3) Payback Period (PP)

This analysis is intended to know how much time needed to get the fund invested for the trevally culture back. The calculation indicates that the invested fund could be regained in 0.88 year or 10.56 months (2.13 of production process.

$\begin{aligned} \mathrm{PP} & =\frac{\text { Total Operational Cost }}{\text { Net Gain }} \\ & =\frac{\text { Rp.736.377.366 }}{\text { Rp.840.000.000 }} \\ & =0.88 \text { year } \\ & =10.56 \text { months }\end{aligned}$

Thus, the trevally culture business is feasible to do since the capital return is shorter than 3-year business period.

4) Net Present Value (NPV)

Net Present Value reflects the money received from the invested funds.

Febryanto W (2008) uttered that a business could be run if the NPV is $\geq 0$ and if the NPV equalled to 0 , the business would return the Social Opportunities of Capital or it is at the break even point. If NPV is $<0$, the business is not feasible to do. The present study showed that the trevally culture in Amurang district (Table 3) receiced the NPV as much as Rp. 47.939.193,- for the investment period with a Net B/C Ratio of 1.17 at the discount rate of $12 \%$ reflecting that the trevally culture investment is financially feasible.

5) B/C Ratio (Benefit Cost Ratio)

$\mathrm{B} / \mathrm{C}$ Ratio is a value or benefit obtained from each possible cost spent, the ratio between total gain and total cost. The higher the $\mathrm{B} / \mathrm{C}$ ratio the higher the profit is obtained. The BCR value of the trevally culture in Amurang district is

$$
\begin{aligned}
\text { BCR } & =\frac{\text { Gain }}{\text { Cost }} \\
& =\frac{840.000 .000}{716.803 .000} \\
& =1.17
\end{aligned}
$$

Net $\mathrm{B} / \mathrm{C}$ of 1.17 means that each expenditure of $\mathrm{Rp} 1$ will give a benefit of $\mathrm{Rp} \mathrm{1.17}$. This value is obtained from total inflow divided by total outflow multiplied by discount rate.

To know the efficiency rate of a busness, the total gains is divided by the total expenditure, where

B/C Ratio > 1 : Efficient

$\mathrm{B} / \mathrm{C}$ Ratio $=1:$ Break even

$\mathrm{B} / \mathrm{C}$ Ratio $<1$ : Inefficient

Hence, the feasibility ratio value of 1.17 indicates that the trevally culture business Amurang district, South Minahasa regency has fulfilled the feasibility requirements.

6) Break Even Point (BEP)

This analysis is intended to know how many product should be sold or how much the selling price is that the company does not get loss. The result shows that to reach the BEP, the production of 3-year trevally culture business is $18,409 \mathrm{~kg}$ or $6,136 \mathrm{Kg}$ per year with a selling price of Rp.35,066,- per $\mathrm{kg}$.

Present field condition indicates that the trevally culture business in Amurang district for 3 years produced $21,000 \mathrm{~kg}$ fish for 10 units of FNC with sellng price of Rp. 40,000/Kg, so that the fish culture got some profit.
a. Production BEP Product Unit Price
$=$ Rp.736.377.366
Rp. 40.000
$=18.409 \mathrm{Kg}$
$=\underline{\text { Total Operational Cost }}$ 


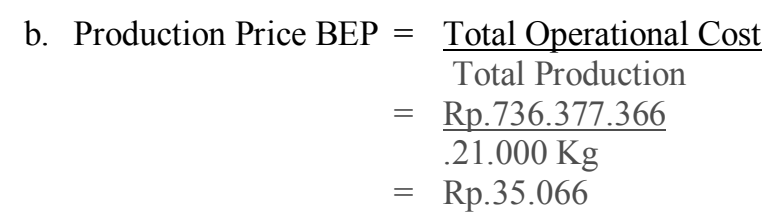

7) Return On Investment (ROI)

This analysis is done to know the capital strength invested in the entire assets in order to get profit.

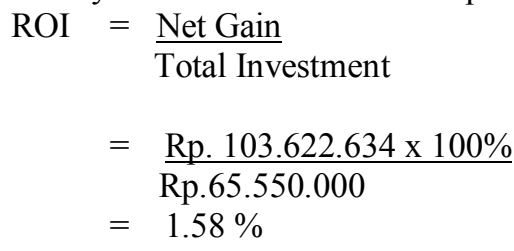

8) Internal Rate of Return (IRR)

IRR used to discount the entire net cash flow and salvage value, will generate the same amount of the present value as the investment project (Sutojo, 2002). The interest rate of IRR reflects maximum interest rate that could be paid by the fish farmer for the capital used. The IRR value of the trevally culture business in Amurang district is $85.27 \%$ indicating that the business could return the capital with an interest rate of $85.27 \%$ per year ( $>$ discount Rate) so that the trevally culture business is still feasible to do up to the interest rate of $85.27 \%$ per year.

\section{Cash Flow Analysis of Investment Feasibility}

This analysis describes the projection of gain and expenditure flows of the flosting net cage system-trevally culture business for 3 years. Based on the cash flow analysis, the trevally culture in Amurang district, South Minahasa regency has given some profit, and it could result from low gains due to limited number of seedlings and trash fish caught around Amurang waters. The cash flow projection of the trevally culture in Amurang district is given in Table 03 .

Table 3. Trevally Culture Business Feasibility in Amurang District.

\begin{tabular}{|c|c|c|c|c|}
\hline \multirow{2}{*}{ Description } & \multicolumn{4}{|c|}{ Year } \\
\hline & 0 & 1 & 2 & 3 \\
\hline \multicolumn{5}{|l|}{ CASH IN FLOW } \\
\hline Production/unit/year (Kg) & & 700 & 700 & 700 \\
\hline Production/10 Unit & & 7.000 & 7.000 & 7.000 \\
\hline Price/Kg & & 40.000 & 40.000 & 40.000 \\
\hline Gain & & 280.000 .000 & 280.000 .000 & 280.000 .000 \\
\hline $\begin{array}{l}\text { CASH OUT FLOW } \\
\text { Investment Cost }\end{array}$ & 65.550 .000 & & & \\
\hline Variabel Cost & 94.277 .500 & 94.277 .500 & 94.277 .500 & 116.897 .360 \\
\hline Fixef Cost & & 49.381 .000 & 49.381 .000 & 49.381 .000 \\
\hline Taxes $15 \%$ & & 42.000 .000 & 42.000 .000 & 42.000 .000 \\
\hline Total Cost & 159.827 .500 & 185.658 .500 & 185.658 .500 & 185.658 .500 \\
\hline Surplus/Deficit & (159.827.500) & 89.627 .625 & 89.391 .931 & 84.430 .578 \\
\hline DF $12 \%$ & 1 & 0,51 & 0,51 & 0,51 \\
\hline PV & (159.827.500) & 47.939 .193 & 47.939 .193 & 47.939 .193 \\
\hline
\end{tabular}

\section{Conclusion}

The trevally culture in Amurang district is feasible to do since the financial analysis exhibits positive NPV, IRR $>\mathrm{DF}, \mathrm{Net} \mathrm{B} / \mathrm{C}>1$, and payback period in the range of project period. However, the profit gained was not optimal yet because the the utilization capacity of the business strength was only half the normal capability. The main cause was low seedling supply and limited food availability. 


\section{References}

[1]. Anonimous.1997. Mariculture Potency in Indonesia. Direktorat Jenderal Perikanan. Jakarta.

[2]. Anonimous, 2001. Fish Resources Utilization Mapping in Madura Strait, Southeren Province of East Java and Java Sea. Final Report of Collaborative Research between Faculty of Fisheries, Brawijaya University and Fisheries and Marine Services of East Java Province.

[3]. Anoimous.2011. South Minahasa Regency Profiles. Marine and Fisheries Services of South Minahasa Regency.

[4]. Febryanto W, 2008. Feasibility Analysis of Tiger Grouper Culture Business in Panggang Island, Administrative Regency of Kepulauan Seribu, DKI Jakarta. Extension S1 Program of Agribusiness Management, Faculty of Fisheries, Pertanian Institut Pertanian Bogor

[5]. Dahuri, R. 2002. New Paradigm of Marine-Based Indonesia Development. Scientific Oration for Professorship Promotion on Coastal and Marine Resources Management. IPB. 233 p.

[6]. Nikijuluw.2002. Fisheries Resources Management Rezime. Pustaka Cindesindar. Jakarta.254 p

[7]. Nikijuluw, V.P.H., 2002. Capital and Investment Policy of Fisheries Sector Development at the Regional levels. Paper presented in "Indonesia Agribisnis 2002 Expo" - Agribusiness Sector Investment Opportunity in Autonomous era in World Trade Center, Surabaya, October 9, 2002.

[8]. Rini Andriyani.2008. Feasibility and Development Strategy of Fish Farmer Group Business Through "Replika SKIM Modal" Program. Thesis. IPB Bogor. 104 p.

[9]. Sudirman dan Yursi, 2008. Grouper: Biology, Exploitation, Management, and Culturebiologi,eksploitasi,manajemen. Yarsif watampone. Jakarta.

[10]. Sutojo S. 2002. Project Feasibility Study: Concept, Technique and Case. Jakarta : PT Damar Mulia Pustaka 